\title{
PENGARUH PEMBERIAN AIR REBUSAN DAUN ALPUKAT TERHADAP PENURUNAN TEKANAN DARAH PADA USIA LANJUT DENGAN HIPERTENSI
}

\author{
Mei Krismon Laoli*, Rosmianti Ge’e, Putri Novi Yanti Halawa, Rotua Sumihar Sitorus, \\ Eva Latifah Nurhayati
}

Fakultas Keperawatan dan kebidanan,Universitas Prima Indonesia, Jl. Danau Singkarak, Gg. Madrasah, Sei Agul, Kec. Medan Barat, Kota Medan, Sumatera Utara 20117, Indonesia

*krismonlaoli@gmail.com (+6282273771531)

\begin{abstract}
ABSTRAK
Penyakit Hipertensi atau tekanan darah tinggi merupakan peningkatan tekanan darah persisten yang juga dijuluki pembunuh diam-diam atau silent killer karena tidak memilki gejala yang khas sehingga seseorang yang mengidap hipertensi selama bertahun-tahun tidak menyadari sampai terjadi kerusakan organ vital yang cukup berat yang bahkan dapat menyebabkan kematian. Lanjut usia (lansia) adalah bagian dari proses tumbuh kembang manusia tidak secara tiba-tiba menjadi tua, tetapi berkembangnya dari bayi, anak-anak, dan dewasa akhirnya menjadi tua. Daun alpukat merupakan salah satu tanaman yang memiliki manfaat sebagai obat herbal.. Tujuan penelitian ini untuk mengetahui adanya penurunan tekanan pada usia lanjut dengan hipertensi melalui pemberian air rebusan daun alpukat di UPT puskesmas rantang medan tahun 2021. Jenis Penelitian ini pre-posttest control group design. Alat ukur yang digunakan adalah lembar koesioner, observasi dan SOP. Hasil penelitian yang diperoleh melalui uji Wilcoxon Test yaitu adanya Pengaruh Pemberian Air Rebusan Daun Alpukat Terhadap Penurunan Tekanan Darah Pada Usia Lanjut Dengan Hipertensi di UPT Puskesmas Rantang Medan Tahun 2021.
\end{abstract}

Kata kunci: daun alpukat; hipertensi; lanjut usia

\section{THE INFLUENCE OF PROVISION OF AVOCOLE LEAVES BOOKED WATER ON BLOOD PRESSURE REDUCTION IN THE ELDERLY AGE WITH HYPERTENSION}

\begin{abstract}
Diseases Hypertension or high blood pressure is an increase in blood pressure and persistent also dubbed the silent killer or a silent killer because it does not have the typical symptoms that a person who suffered from hypertension for many years did not realize until the damage to the vital organs are severe enough that it can even cause Dead. Elderly ( elderly) is part of the process of human growth and development, not suddenly getting old, but the development of infants, children, and adults eventually becoming old. Avocado plant (Persea americana Mill) is one of the plants that has benefits as traditional medicine. Almost all parts of this plant have properties as a source of medicine. The purpose of this study was to analyze the effect of giving avocado leaf boiled water on the reduction of blood pressure in the elderly with hypertension at the UPT Puskesmas Rantang Medan in 2021. This study is a pre-posttest control group design. Measuring instrument used is the observation sheet and Aneroid sphygmomanometer. The results of the research obtained through the Wilcoxon Test were that there was an effect of giving water boiled avocado leaves on reducing blood pressure in the elderly with hypertension at UPT Puskesmas Rantang Medan in 2021.
\end{abstract}


Keywords: avocado leaf; elderly; hypertension

\section{PENDAHULUAN}

Makanan berlemak.asin dan siap saji merupakan makanan yang sering dikonsumsi oleh masyarakat pada umumnya sehingga memicu timbulnya kolesterol tinggi. Salah satu pemicu hipertensi yaitu kolestrol tinggi.. Dimana tekanan darah tinggi dapat menyebabkan penyakit jantung dan stroke. salah satu faktor terjadinya penyakit berat seperti serangan jantung dan stroke (Yusri \& Febriyanti, 2019). seseorang yang mengalami hipertensi saat tekanan sistolik mencapai di atas $140 \mathrm{mmHg}$ dan tekanan diastolik di atas $90 \mathrm{mmHg}$ (Isnaini \& Fulanah, 2019). Dampak yang dialami oleh seorang yang mengalami penyakit hipertensi yaitu nyeri kepala,sesak, susah tidur, aritmia, mimisan, kebas, dan gampang marah, keringat berlebihan,badan lemah, odem di bawah mata pada pagi hari. Perubahan gaya hidup seperti merokok, minum alkohol, diet yang tidak teratur dan jarang berolaharaga salah satu penyebab hipertensi. (Isnaini \& Fulanah, 2019). Menurut WHO (World health organization) terdapat sekitar 972 $(26,4 \%)$ orang dengan hipertensi. dimana presentase antara laki-laki $26,6 \%$ dan perempuan 26,1\%. Angka ini diperkirakan akan meningkat menjadi 29,2\% ditahun 2025 .

Diantara Myanmar, India, Srilanka, Bhutan, Thailand, Nepal, dan Maldives, Indonesia berada diperingkat 10 negara dengan pengidap hipertensi terbesar di dunia, (Anonim, 2013). Berdasarkan data yang didapatkan dari Riskesdas Tahun 2013, terjadi peningkatan prevalensi hipertensi dari $25,8 \%$ menjadi $34,1 \%$ pada tahun 2018. Di Provinsi Sulawesi Utara angka hipertensi 15,2\% dan di Propinsi papua
3,3\%. (Yusri \& Febriyanti, 2019). Data hipertensi yang di peroleh dari Dinas Kesehatan Provinsi Sumatera Utara adalah $50.162 \quad$ (25.0\%). Jumlah terbanyak yang menderita hipertensi berdasarkan dari data tersebut ialah wanita usia 55 tahun keatas sebanyak $27.021 \quad(13,5 \%)$. (Dinas Kesehatan Provinsi Sumatera Utara, 2018). Upaya pencegahan hipertensi yang hasilnya belum memuaskan terbukti dari masih tingginya kasus hipertensi sebagaimana data yang diuraikan diatas. Lanjut usia (lansia) yang menjadi subjek penelitian adalah lansia dengan usia 60-70 tahun yang ada di Puskesmas Rantang Kecamatan Medan Petisah.

Kota Medan sebagai salah satu wilayah di Provinsi Sumatera Utara dimana salah satu Kecamatannya adalah Medan Petisah sebagai tempat penelitian ini dilakukan yaitu Puskesmas Rantang memiliki data lansia dengan hipertensi sebanyak 75 $(11,1 \%)$ (Dinas Kesehatan Kota Medan 2020). Penatalaksanaan hipertensi dapat dilakukan dengan dua cara yaitu secara farmakologi dan secara nonfarmakologi. Dimana penatalaksanaan secara farmakologi dengan memperhatikan tingkat kepatuhan dan mekanisme kerja, terdiri dari obat diuretik, Hidrocortison, vasodilator, simpatetik, betabloker. Mengonsumsi obat dalam jangka waktu yang panjang dapat menimbulkan efek yang tidak baik dalam tubuh. Penatalaksanaan non farmakologi yaitu dengan merubah gaya hidup, seperti menjaga berat badan ideal, mengurangi konsumsi makanan yang berlemak, olahraga secara teratur, dan dengan terapi komplementer seperti air rebusan daun alpukat dapat menurunkan 
tekanan darah (Margowati \& Wiharyani, 2016).

Berdasarkan uraian latar belakang diatas peneliti ingin mencoba melakukan pemberian air rebusan daun alpukat kepada lansia penderita hipertensi sebagai upaya pencegahan terhadap permasalahan yang terjadi pada lansia diwilayah kerja Puskesmas Rantang serta dapat membantu lansia dalam mempertahankan Kesehatan yang optimal secara mandiri.

\section{METODE}

Jenis penelitian ini menggunakan Quasi Eksprerimental design yang bersifat kuantitaf dengan rancangan pre-posttest control group design, pada penelitian ini ada dua kelompok responden yaitu kelompok eksperimen dan kelompok kontrol dengan subjek yang sama (Nursalam, 2016). Penelitian ini membandingkan antara kelompok perlakuan dan kelompok kontrol. Tujuan dari penelitian adalah untuk mengetahui adanya pengaruh sebelum dan sesudah pemberian air rebusan daun alpukat terhadap penuruan tekanan darah pada lansia dengan hipertensi. Pengukuran dalam penelitian ini dilakukan sebanyak 2 kali yaitu sebelum dilakukan dan sesudah ekperimen (pre-post test).

Penelitian dilakukan di Wilayah Kerja Puskesmas Rantang Kecamata Medan Petisah dan Waktu Pelaksanaan penelitian direncanakan bulan Maret 2021. Populasi dalam penelitian ini adalah seluruh pasien penderita hipertensi dii Puskesmas Rantang Medan yang berjumlah 75 orang. Sampel Besar sampel dalam penelitian ini dihitung dengan menggunakan rumus Sugiyono (2017) didapatkan jumlah sampel sebanyak 30 orang.
Alat ukur yang digunakan dalam penelitian ini adalah kuesioner tentang hipertensi, Sphygmomanometer Aneroid (GEA), dan lembar observasi kejadian hipertensi. Kuesioner tentang hipertensi Dengan skala yang relevan dengan skala ordinal dimana responden menjawab salah satu jawaban yang disediakan. Pilih jawaban sesuai item pertanyaan,Ya skor "1" jika melakukan dan Tidak skor "0" jika tidak melakukan. Lembar observasi hipertensi Lembar observasi ini berisi pertanyaan dan dibuat dalam bentuk checklist dengan cara peneliti memberikan tanda checklist pada kolom penilaian. Dengan alternatif penilaian dalam bentuk kelompok kontrol dan intervensi berupa jawaban Ya skor "1" jika aspek yang diamati terlaksana dan Tidak skor " 0 " jika aspek yang diamati tidak terlaksana. Variabel independen dalam penelitian ini adalah pemberian air rebusan daun alpukat. Variabel dependen dalam penelitian ini adalah penurunan tekanan darah pada lansia. Datadianalisis sevara univariat dan bivariate.

\section{HASIL}

\section{Karakteristik Responden}

Berdasarkan tabel 1 diketahui bahwa dari 30 responden, dominan responden berjenis kelamin perempuan sebanyak 20 orang $(66.7 \%)$ sedangkan minoritas responden laki-laki hanya sebanyak 10 orang (33.3\%). Usia keseluruhan responden adalah 60 - 70 Tahun (100\%). Pendidikan mayoritas responden adalah SMP yakni 15 orang $(50 \%)$ sedangkan minoritas responden adalah yang berpendidikan tamat S1 hanya 1 orang (3.3\%). Berikutnya responden bekerja yakni sebanyak 15 orang $(50 \%)$ dan tidak bekerja juga sebanyak 15 orang $(50 \%)$. 
Tabel 1.

Karakteristik Responden

\begin{tabular}{|c|c|c|c|}
\hline \multicolumn{2}{|c|}{ Karateristik } & $\mathrm{f}$ & $\%$ \\
\hline \multirow[t]{2}{*}{ Jenis Kelamin } & Perempuan & 20 & 66,7 \\
\hline & Laki-Laki & 10 & 33,3 \\
\hline Usia & 60 - 70 Tahun & 30 & 100 \\
\hline \multirow[t]{4}{*}{ Pendidikan } & $\mathrm{S} 1$ & 1 & 3,3 \\
\hline & SMA & 3 & 10 \\
\hline & $\mathrm{SD}$ & 11 & 36,7 \\
\hline & SMP & 15 & 50 \\
\hline \multirow[t]{2}{*}{ Pekerjaan } & Bekerja & 15 & 50 \\
\hline & Tidak Bekerja & 15 & 50 \\
\hline
\end{tabular}

Tabel 2.

Pengetahuan tentang Pemberian Air Rebusan Daun Alpukat untuk Menurunkan Tekanan Darah $(\mathrm{n}=30)$

\begin{tabular}{lcc}
\hline Pengetahuan & f & $\%$ \\
\hline $50-69 \%$ & 6 & 20 \\
$70-100 \%$ & 24 & 80 \\
\hline
\end{tabular}

Tabel 3.

Tekanan darah Sebelum Diberikan Air Rebusan Daun Alpukat ( $\mathrm{n}=30)$

\begin{tabular}{lcc}
\hline \multicolumn{1}{c}{ Tekanan Darah } & $\mathrm{f}$ & $\%$ \\
\hline$<120 /<80 \mathrm{mmHg}$ & 5 & 16.7 \\
$140-159 / 90-99 \mathrm{mmHg}$ & 9 & 30.0 \\
$120-139 / 80-89 \mathrm{mmHg}$ & 16 & 53.3 \\
\hline
\end{tabular}

Tabel 4.

Tekanan darah Setelah Diberikan Air Rebusan Daun Alpukat (n=30)

\begin{tabular}{lcc}
\hline \multicolumn{1}{c}{ Tekanan darah } & f & $\%$ \\
\hline $140-159 / 90-99 \mathrm{mmHg}$ & 2 & 6.7 \\
$120-139 / 80-89 \mathrm{mmHg}$ & 6 & 20.0 \\
$<120 /<80 \mathrm{mmHg}$ & 22 & 73.3 \\
\hline
\end{tabular}

Tabel 2 diketahui bahwa mayoritas responden mengetahui tentang hipertensi dan untuk menurunkan tekanan darah dapat dilakukan dengan meminum air rebusan daun alpukat.

Tabel 3 diketahui bahwa sebelum dilakukan pemberian air rebusan daun alpukat mayoritas responden memiliki tekanan darah 120- 139/80- $89 \mathrm{mmHg}$ dan minoritas $<120 /<80 \mathrm{mmHg}$

Tabel 4, diketahui bahwa setelah diberikan air rebusan daun alpukat maka mayoritas responden memiliki tekanan darah $<120 /<80 \mathrm{mmHg}$ dan minoritas $140-159 / 90-99 \mathrm{mmHg}$. 
Tabel 5 .

Tekanan Darah Sebelum dan Sesudah diberikan Air Rebusan Daun Alpukat (n=30)

\begin{tabular}{l|l|c|c|c}
\hline \multicolumn{1}{r|}{ Tekanan Darah } & $\mathrm{n}$ & MEAN & SD & MIN - MAX \\
\hline Pre & 30 & 1.87 & 0.681 & $1-3$ \\
Post & 30 & 2.87 & 0.606 & $1-3$ \\
\hline
\end{tabular}

Tabel 6.

Hasil Uji Deskripsi Wilcoxon Signed Ranks Test Perubahan Tekanan Darah

\begin{tabular}{|c|c|c|c|c|}
\hline Tekanan Darah & $\mathrm{N}$ & Mean & $\mathrm{Z}$ & $P$-Value \\
\hline Pre & 30 & 1.87 & \multirow{2}{*}{$-3.577^{\mathrm{a}}$} & \multirow{2}{*}{0,000} \\
\hline Post & 30 & 2.87 & & \\
\hline
\end{tabular}

Tabel 5 menunjukkan bahwa ratarata tekanan darah sebelum diberikan air minum rebusan daun alpukat adalah 1.87 dan setelah diberikan yaitu rata-rata 2.87. Nilai minimal tekanan darah pada pre yaitu 1 dan nilai maksimalnya yakni 3 sedangkan pada post nilai minimal adalah 1 dan nilai maksimal 3.

Tabel 6 diketahui bahwa skor perubahan tekanan darah hasil uji wilcoxon pada saat di uji pre test hasil nilai mean 1.87, pada saat di uji Post test dengan hasil mean 2.87. Jadi yang didapat hasil nilai $\mathrm{Z}=-3.557$ maka $p$ value sebanyak $0,000<0,05$ sehingga disimpulkan $\mathrm{Ho}$ di tolak dan $\mathrm{Ha}$ terima, yang artinya Ada Pengaruh Konsumsi Air Rebusan Daun Alpukat Terhadap Penurunan Tekanan Darah Pada Lansia Penderita Hipertensi.

\section{PEMBAHASAN}

Tekanan darah sebelum pemberian Air Rebusan Daun Alpukat

Hipertensi merupakan penyakit yang tidak menimbulkan gejala khas sehingga sering tidak terdiagnosis waktu yang lama, batas tekanan darah yang normal vadalah 140/90 mmHg(WHO,2014). Masa tua merupakan masa yang kurang menyenangkan, dimana dengan bertambahnya umur, fungsi fisiologis mengalami akibat proses penuaan sehingga penyakit tidak menular banyak muncul.

Pengobatan hipertensi adalah mengendalikan tekanan darah untuk mencegah terjadinya komplikasi, adapun penatalaksanaannya sebagai berikut: 1)Farmakologi yaitu dengan memperhatikan tingkat kepatuhan dan mekanisme kerja, terdiri dari obat diuretik, Hidrocortison, vasodilator, simpatetik, betabloker, nifedipine, dan amblodipin. Mengonsumsi obat dalam jangka waktu yang panjang dapat menimbulkan efek yang tidak baik dalam tubuh. 2)Non-farmakologi yaitu dengan merubah gaya hidup, seperti menjaga berat badan ideal, mengurangi konsumsi makanan yang berlemak, olahraga secara teratur, dan dengan terapi komplementer seperti Air Rebusan Daun Alpukat (Margowati, Priyanto \& Wiharyani, 2016)

Tanaman alpukat (Persea americana Mill) merupakan salah satu tanaman yang memiliki manfaat sebagai obat tradisional. Hampir semua bagian dari tanaman ini memiliki khasiat sebagai sumber obat-obatan. (Lisfaresliana Hasjim, 2017). Berdasarkan hasil penelitian terhadap 30 responden tentang Pengaruh Pemberian Air Rebusan Daun Alpukat Terhadap Penurunan Tekanan Darah Pada Usia Lanjut 
dengan Hipertensi di UPT

Puskesmas Rantang Medan Tahun 2021 diketahui bahwa sebelum diberikan air rebusan daun alpukat mayoritas tekanan darah $120-139 / 80-$ $89 \mathrm{mmHg}$ dan minoritas $<120 /<80$ $\mathrm{mmHg}$.

\section{Tingkat Tekanan darah setelah pemberian Air Rebusan Daun Alpukat}

Pemberian air rebusan daun alpukat (Persea Americana Mill) yang mulai diberikan hari pertama kepada penderita hipertensi usia 60 tahun keatas, memberikan efek yang bermakna terhadap penurunan tekanan darah sistol dan diastol pada hari berikutnya, meskipun terjadi penurunan dan kenaikan pada hari tertentu.Hal tersebut sesuai pernyataan responden karena kelelahan, stres, banyak pikiran, dan tidak bisa istirahat dengan cukup, ehingga faktor-faktor tersebut menjadi penyebab naik dan turunnya tekanan darah. Rebusan daun alpukat (Persea Americana Mill) yang diberikan setiap hari secara berturut-turut sedikitnya sekali sehari sebanyak $200 \mathrm{cc}$ telah memberikan efek yang baik terhadap penurunan tekanan darah pada penderita hipertensi usia 60 tahun keatas (Priyanto, Sigit \& Robiul Fitri Masithoh. 2018).

Berdasarkan hasil penelitian terhadap 30 responden tentang pengaruh pemberian air rebusan daun alpukat terhadap penurunan darah pada usia lanjut dengan hipertensi di UPT Puskesmas Rantang Medan Tahun 2021 diketahui bahwa setelah maka mayoritas responden memiliki tekanan darah $<120 /<80$ $\mathrm{mmHg}$ dan minoritas 140-159/90-99 mmHg.

\section{Pengaruh Pemberian Air Rebusan \\ Daun Alpukat Terhadap Penurunan Tekanan Darah Pada Usia Lanjut Dengan Hipertensi}

Hasil penelitian dari Uji Wilxocon Rank menunjukkan $\rho$ value $=0,000<\alpha=0,05$, hal ini berarti $\mathrm{H}_{0}$ ditolak dan $\mathrm{H}_{\mathrm{a}}$ diterima artinya adanya penurunan tekanan pada usia lanjut dengan hipertensi melalui pemberian air rebusan daun alpukat di UPT puskesmas rantang medan tahun 2021. Hasil penelitian ini sesuai dengan pendapat Anna Lusia Kus (2011) dimana dengan menggunakan terapi herbal yang diyakini rendah efek samping, mudah dan murah yaitu dengan menggunakan daun alpukat.

\section{SIMPULAN}

Sebelum diberikan air rebusan daun alpukat mayoritas tekanan darah responden 120 - 139/80- $89 \mathrm{mmHg}$ dan minoritas $<120 /<80 \mathrm{mmHg}$. Setelah diberikan air rebusan daun alpukat mayoritas tekanan darah responden $<120 /<80 \mathrm{mmHg}$ dan minoritas 140159/90-99 mmHg. Ada pengaruh pemberian air rebusan daun alpukat terhadap penurunan tekanan darah pada usia lanjut dengan hipertensi ( $\mathrm{p}$ value = 0,000 ).

\section{DAFTAR PUSTAKA}

Amran, Y. (2010). Pengaruh Tambahan Asupan Kalium dari Diet terhadap Penurunan Hipertensi Sistolik Tingkat Sedang pada Lanjut Usia. Jurnal Kesehatan Masyarakat Nasional, 5(3), 125-130.

D. Kusumawardani, dkk Journal Research Midwifery Politekni Tegal 7 (1). 2018

Emmelia, (2015) Asuhan Keperawatan Gerontik, Yogyakarta : Pustaka Baru Press. 
Hasjim, Limfaresliana. 2017. Uji Daya Hambat sari Daun Alpukat (Presea Americana Mill) Terhadap Pertumbuhan Escherichia coli. Politekni Kesehatan Kendari.

Isnaini, N., \& Fulanah, U. (2019). Penurunan tekanan darah dengan simplisia daun alpokat Decreasing blood pressure with avoid simplicia leaves. Journal of Health Studies, 3(1), 44-52. https://doi.org/10.31101/jhes.839

Margowati, S., Priyanto, S., \& Wiharyani, M. (2016). Efektivitas Pengunaan Rebusan Daun Alpukat Dengan Rebusan Daun Salam Dalam Penurunan Tekanan Darah Pada Lansia. Universty Research Coloquium, 234-248.

Nursalam. (2017). Konsep Dan Penerapan Metodologi Penelitian Ilmu Keperawatan. Jakarta : Salemba Medika.

Priyanto, S., \& Masithoh, F. R. (2018). Efektivitas rebusan daun alpukat terhadap tekanan darah pada lansia hipertensi. Jurnal Ilmu Keperawatan Dan Kebidanan (JIKK), 3(3), 188. http://digilib.unisayogya.ac.id/306 2/1/NASKAH PUBLIKASI.pdf

Sugiono. (2017) Metode Penelitian, Kuantitatif, Kualitatif dan R\&D. Bandung : Alfabeta, CV

Riskesdas, K. (2018). Hasil Utama Riset Kesehata Dasar (RISKESDAS). Journal of Physics A: Mathematical and Theoretical, 44(8), 1-200. https://doi.org/10.1088/1751$8113 / 44 / 8 / 085201$

Setyawan, B. A. (2018). Jurnal ilmu kesehatan vol.6 no. 1 juni 2018. 6(1), 1-10.

Tim Bumi Medika (2017) Berdamai dengan Hipertensi. Jakarta : Bumi Medika

UUD RI N0.13. Tahun 1998 Kesejateraaan Lanjut Usia.

World Health Organization (WHO). 2014. Data Hipertensi Global. Asia Tenggara : WHO.

Yusri, V., \& Febriyanti. (2019). Pengaruh Pemberian Rebusan Daun Alpukat (Persea americana mill) Terhadap Penurunan Tekanan Darah Pasien Hipertensi Primer di Wilayah Kerja Puskesmas Nanggalo. Menara Ilmu, XIII(5), 231-236. https://www.jurnal.umsb.ac.id/ind ex.php/menarailmu/article/view/1 $\underline{429 / 126 .}$. 
Jurnal Penelitian Perawat Profesional, Volume 3 No 2 Hal 391 - 398, Mei 2021

Global Health Science Group 